Available online at : http://journal.unj.ac.id/unj/index.php/gjik

Gladi Jurnal Ilmu Keolahragaan 07 (02) 2013, 733 - 745

Permalink/DOI: https://doi.org/10.21009/GJIK.072.01

\title{
PREVALENSI HIPERTENSI BERDASARKAN INDEKS MASSA TUBUH \\ PADA DOSEN UMUR 40-59 TAHUN DI LINGKUNGAN UNIVERSITAS PENDIDIKAN GANESHA SINGARAJA
}

\section{Gede Doddy Tisna MS ${ }^{1}$}

\begin{abstract}
Abstrak, Penelitian ini bertujuan untuk mengetahui untuk mengetahui prevalensi hipertensi berdasarkan indeks massa tubuh pada dosen umur 40-59 tahun di lingkungan Universitas Pendidikan Ganesha tahun 2011. Jenis penelitiann ini adalah penelitian ini merupakan penelitian deskriptif cross sectional yang akan memaparkan tentang angka prevalensi hipertensi berdasarkan indeks massa tubuh pada dosen-dosen Universitas Pendidikan Ganesha yang berumur 40-59 tahun. Sampel dalam penelitian ini diambil dengan teknik random sampling, dengan perhitungan jumlah sampel menggunakan tabel Krejcie, yang mempunyai kepercayaan 95\%. Besar sampel yang didapatkan dalam penelitian ini adalah 140 orang. Data diperoleh dengan mengukur tekanan darah dikelompokkan berdasarkan kriteria JNC VII, untuk indeks massa tubuh dikelompokkan berdasarkan kriteria WHO (1998). Perhitungan prevalensi dengan menggunakan rumus point prevalence rate. Selanjutnya untuk menganalisis distribusi masing-masing variabel dilakukan analisis univariat. Kemudian untuk mengetahui kekuatan hubungan antara 2 variabel dilakukan analisis korelasi pearson product moment. Hasil yang diperoleh pada penelitian ini, persentase penderita hipertensi dosen umur 40-59 tahun di lingkungan Undiksha adalah 12,4 $\%$ (17 orang) dari total sampel 140 orang. Persentase penderita hipertensi yang mengalami obesitas sebanyak $11,76 \%$ (2 orang). Persentase penderita hipertensi yang mengalami kegemukan sebanyak 82,53 \% (14 orang). Sedangkan Persentase penderita hipertensi yang indek masa tubuhnya normal sebanyak $0,58 \%$ (1 orang).
\end{abstract}

Kata Kunci: Hipertensi, Umur, Obesitas.

\footnotetext{
${ }^{1}$ Gede Doddy Tisna MS adalah Dosen pada Jurusan Pendidikan Jasmani dan Kesehatan Fakultas Olahraga dan Kesehatan, Universitas Pendidikan Genesha
} 


\section{PENDAHULUAN}

Hipertensi menjadi masalah kesehatan secara global, karena tingginya frekuensi kejadiannya dan tingginya resiko untuk menjadi penyakit kardiovaskular dan penyakit ginjal. Hipertensi merupakan faktor resiko penyebab kematian dan di dunia menempati urutan ketiga yang dapat menyebabkan kecacatan (Kearney et al., 2005). Hipertensi juga dikenal dengan pembunuh terselubung atau silent killer karena sifatnya yang tidak menimbulkan gejala.

Menurut data Riskesdas (2007), prevalensi kejadian hipertensi di Indonesia mencapai 31 persen, sedangkan di Bali mencapai 29 persen. Dan prevalensi kejadian hipertensi meningkat sesuai dengan bertambahnya umur (Badan Penelitian dan Pengembangan Kesehatan, 2008). Menurut data Dinas Kesehatan Kabupaten Buleleng tahun 2010, hipertensi menempati urutan ketiga pada 10 besar penyakit terbanyak di buleleng yaitu sebanyak 16,7 \% (Dinas Kesehatan Kabupaten Buleleng, 2010).

Undiksha sebagai salah satu lembaga yang senantiasa berusaha meningkatkan mutu pendidikan bangsa, dimana salah satu yang berperan peting adalah tenaga pengajarnya (dosen) harus berkualitas. Kesehatan sangat mendukung kualitas dan profesionalitas dosen untuk memberikan proses pembelajaran yang berkualitas. Menurut pengamatan dilapangan, terdapat gaya hidup yang kurang bagus pada dosen di lingkungan Undiksha, dimana sebagian besar pekerjaannya diselesaikan di tempat duduk (sedentary life).

Data dosen Undiksha tahun 2011 sejumlah 438 orang, dari jumlah tersebut rentangan umur 20-39 tahun sejumlah 173 orang dan 40-59 tahun sejumlah 212 orang, dan diatas 60 tahun sebanyak 53 orang. Dari jumlah tersebut rentangan umur 40-59 tahun adalah yang paling banyak, dimana rentangan umur tersebut merupakan resiko yang paling besar terjadinya kejadian hipertensi.

Berdasarkan latar belakang masalah yang ingin dipecahkan dalam penelitian ini, yaitu berapakah prevalensi hipertensi berdasarkan indeks massa tubuh pada dosen umur 40-59 tahun di lingkungan Undiksha Tahun 2011, dan apakah ada hubungan 
antara hipertensi dengan indeks massa tubuh pada dosen umur 40-59 tahun di lingkungan Undiksha Tahun 2011.

Manfaat yang bisa diperoleh dari penelitian ini, yaitu: dapat memberikan informasi tentang besar jumlah penderita hipertensi di lingkungan dosen Undiksha, secara khusus untuk klinik Undiksha, sehingga dapat digunakan sebagai deteksi dini dalam mencegah kejadian hipertensi dan dapat memberikan informasi tentang hubungan hipertensi dan indeks massa tubuh.

\section{LANDASAN TEORI}

Hipertensi atau tekanan darah tinggi merupakan masalah kesehatan yang paling sering kita temui. 1 dari 4 orang dewasa di seluruh dunia berpotensi untuk menderita hipertensi. Hipertensi juga disebut pembunuh terselubung atau silent killer karena tidak menimbulkan gejala dan bisa menjadi masalah kesehatan yang serius jika tidak di obati dalam waktu yang cukup lama (Essential hypertension, 2008).

Menurut National Health and Nutrition Examination Survey (NHANES), di amerika angka prevalensi penderita hipertensi mencapai 28,7 \% atau sekitar 58 juta individu. Dan prevalensi penderita hipertensi terjadi pada umur $\geq 60$ tahun sebanyak 64,5\% (Fauci \& Longo, 2008). 7 juta angka kematian di seluruh dunia disebabkan oleh hipertensi atau sekitar $13 \%$ dari total prevalensi kematian seluruhnya.

\section{Etiologi}

Resiko relatif hipertensi tergantung pada jumlah dan keparahan dari faktor resiko yang dapat dimodifikasi dan yang tidak dapat dimodifikasi (Fauci et al.,2008). Faktor-faktor yang tidak dapat dimodifikasi antara lain faktor genetik, umur, jenis kelamin, dan etnis. Sedangkan faktor yang dapat dimodifikasi meliputi stres, obesitas, dan nutrisi (Yogiantoro,2006).

\section{Faktor genetik}

Adanya faktor genetik pada keluarga tertentu akan menyebabkan keluarga itu mempunyai risiko menderita hipertensi. Hal ini berhubungan dengan peningkatan 
kadar sodium intraseluler dan rendahnya rasio antara potasium terhadap sodium individu dengan orang tua dengan hipertensi menderita hipertensi dari pada orang yang tidak mempunyai keluarga dengan riwayat hipertensi.

\section{Umur}

Hipertensi merupakan penyakit multifaktorial yang munculnya oleh karena interaksi berbagai faktor. Dengan bertambahnya umur, maka tekanan darah juga akan meningkat. Setelah umur 45 tahun, dinding arteri akan mengalami penebalan oleh karena adanya penumpukan zat kolagen pada lapisan otot, sehingga pembuluh darah akan berangsur-angsur menyempit dan menjadi kaku. Tekanan darah sistolik meningkat karena kelenturan pembuluh darah besar yang berkurang pada penambahan umur (Dreisbach, 2010; Kuswardhani, 2006)

\section{Jenis kelamin}

Prevalensi terjadinya hipertensi pada pria sama dengan wanita. Namun wanita terlindung dari penyakit kardiovaskuler sebelum menopause.

\section{Etnis}

Hipertensi lebih banyak terjadi pada orang berkulit hitam dari pada yang berkulit putih. Pada orang kulit hitam ditemukan kadar renin yang lebih rendah dan sensitifitas terhadap vasopresin lebih besar. Ini disebabkan sekresi rennin yang ditekan oleh ginjal, ketika mendeteksi kelebihan ekskresi natrium. dalam sirkulasi (Dreisbach, 2010).

\section{Obesitas}

Menurut Hall (1994) perubahan fisiologis dapat menjelaskan hubungan antara kelebihan berat badan dengan tekanan darah, yaitu terjadinya resistensi insulin dan hiperinsulinemia, aktivasi saraf simpatis dan sistem renin-angiotensin, dan perubahan fisik pada ginjal. Peningkatan konsumsi energi juga meningkatkan insulin plasma, dimana natriuretik potensial menyebabkan terjadinya reabsorpsi natrium dan peningkatan tekanan darah secara terus menerus (Cortas, 2008). 


\section{Stres}

Stress akan meningkatkan resistensi pembuluh darah perifer dan curah jantung sehingga akan menstimulasi aktivitas saraf simpatis. Adapun stress ini dapat berhubungan dengan pekerjaan, kelas sosial, ekonomi, dan karakteristik personal (Kulkarni et al,1998)

\section{Nutrisi}

Badan kesehatan dunia yaitu World Health Organization (WHO) merekomendasikan pola konsumsi garam yang dapat mengurangi risiko terjadinya hipertensi. Kadar sodium yang direkomendasikan adalah tidak lebih dari 100 mmol (sekitar 2,4 gram sodium atau 6 gram garam) perhari (Shapo et al, 2003)

\section{Klasifikasi Tekanan Darah}

Tekanan darah diklasifikasikan berdasarkan pengukuran rata-rata dua kali pengukuran masing-masing kunjungan. Menurut Menurut Seventh Report of Joint National Committee on Prevention, Detection, Evaluation and Treatment of High Blood Pressure (JNC 7)

Tabel 1. Klasifikasi Tekanan Darah Menurut JNC VII (National Institute of Health, 2003)

\begin{tabular}{|c|c|c|}
\hline Kategori & Sistolik (mmHg) & Diastolik (mmHg) \\
\hline & $<120$ & $<80$ \\
\hline & 120-139 & 80-89 \\
\hline & $\geq 140$ & $\geq 90$ \\
\hline & $\geq 160$ & $\geq 100$ \\
\hline
\end{tabular}

\section{Patofisiologi}

Mekanisme terjadinya hipertensi adalah melalui terbentuknya angiotensin II dari angiotensin I oleh angiotensin converting enzyme (ACE). ACE memegang 
peranan penting dalam mengatur tekanan darah. Darah mengandung angiotensinogen yang diproduksi di hati. Selanjutnya oleh hormone rennin yang diproduksi di ginjal akan diubah menjadi angiotensin I. Oleh ACE yang terdapat di paru-paru akan diubah menjadi angiotensin II. Angiotensin II inilah yang memegang peranan penting dalam menaikkan tekanan darah. melalui dua aksi utama (Fauci \& Longo, 2008).

\section{Komplikasi}

Hipertensi yang tidak diobati akan menyebabkan komplikasi yang bisa menyebabkan penurunan kualitas hidup penderita itu sendiri. Komplikasi tersebut antara lain penyakit jantung, stroke, gagal ginjal, gagal jantung kongestif, kerusakan otak (ensefalopati), penyakit arteri perifer, kebutaan, bahkan bisa menjadi kematian. Mortalitas pada pasien hipertensi lebih cepat apabila penyakitnya tidak terkontrol dan telah menimbulkan komplikasi ke beberapa organ vital. Sebab kematian yang sering terjadi adalah penyakit jantung dengan atau tanpa disertai stroke dan gagal ginjal (High Blood Pressure Complication, 2007)

\section{Indeks Massa Tubuh}

Tabel 2. Klasifikasi berat badan pada orang dewasa berdasar IMT (WHO, 1998)

\begin{tabular}{|l|l|l|}
\hline Klasifikasi & IMT $\mathbf{( k g / \mathbf { m } ^ { 2 } )}$ & Risiko komorbiditas \\
\hline Kurus & $<18,5$ & $\begin{array}{l}\text { Rendah (tetapi risiko masalah klinis } \\
\text { lain meningkat) }\end{array}$ \\
\hline Batas normal & $18,5-24,9$ & Average \\
\hline Kelebihan berat badan & $\geq 25$ & Meningkat \\
\hline Obese I & $30-34,9$ & Berat \\
\hline Obese II & $35-39,9$ & Sangat berat \\
\hline Obese III & $\geq 40$ & \\
\hline
\end{tabular}




\section{METODE PENELITIAN}

Penelitian ini merupakan penelitian deskriptif cross sectional yang akan memaparkan tentang angka prevalensi hipertensi berdasarkan indeks massa tubuh pada dosen-dosen UNDIKSHA yang berumur 40-59 tahun

Populasi dalam penelitian ini adalah dosen-dosen di Universitas Pendidikan Ganesha, yaitu sebanyak 212 orang. Sampel dalam penelitian ini diambil dengan teknik random sampling, dengan perhitungan jumlah sampel menggunakan tabel Krejcie, yang mempunyai kepercayaan 95\%. Besar sampel yang didapatkan dalam penelitian ini adalah 140 orang.

Teknik pengumpulan data pada penelitian ini:

1. Hipertensi diperoleh melalui pemeriksaan tekanan darah dengan menggunakan sphygmomanometer air raksa merek Riester.

2. Indeks Massa Tubuh diperoleh dengan menggunakan rumus berat badan/tinggi ${ }^{2}$ $\left(\mathrm{kg} / \mathrm{m}^{2}\right)$.

3. Umur diperoleh berdasarkan wawancara langsung menggunakan form biodata subjek penelitian.

Data yang terkumpul dianalisis dengan bantuan komputer dengan menggunakan perangkat lunak program SPSS 16.0. Perhitungan prevalensi dengan menggunakan Rumus : Point Prevalence Rate. Selanjutnya untuk menganalisis distribusi masing-masing variabel dilakukan analisis univariat. Kemudian untuk mengetahui kekuatan hubungan antara 2 variabel dilakukan analisis korelasi pearson product momen.

\section{HASIL DAN PEMBAHASAN}

Dari 140 sampel yang diteliti dan diperiksa didapatkan hasil sebagai berikut :

1. Apabila dilihat dari variable tekanan darah, jumlah dosen yang menderita hipertensi sebanyak 17 orang, dan dosen yang memiliki tekanan darah normal 
sebanyak 113 orang. Dari presentase dapat ditemukan 12,14\% menderita hipertensi, 87,86\% memiliki tekanan darah dalam batas normal.

2. Apabila dilihat dari indeks massa tubuh, jumlah dosen yang memiliki indeks massa tubuh $\geq 30$ sebanyak 10 orang, $\geq 25$ sebanyak 58 orang dan indeks massa tubuh normal sebanyak 72 orang. Dari presentase dapat ditemukan 7,14 \% menderita obesitas, 41,43 \% menderita overweight, dan 60,43\% dalam batas normal.

3. Dari penelitian juga ditemukan bahwa jumlah sampel yang menderita obesitas dengan hipertensi sebanyak 2 orang, dan obesitas dengan tekanan darah normal sebanyak 8 orang. Presentase penderita obesitas dengan hipertensi 1,42\%, sedangkan obesitas dengan tekanan darah normal 5,71 \%

4. Jumlah sampel yang menderita overweight dengan hipertensi adalah 14 orang, overweight dengan tekanan darah normal sebanyak 44 orang. Presentase overweight dengan hipertensi $10 \%$, sedangkan overweight dengan tekanan darah normal sebanyak 31,42\%

5. Jumlah sampel yang memiliki indeks massa tubuh normal dengan hipertensi sebanyak 1 orang, sampel yang memiliki baik indeks massa tubuh dan tekanan darah dalam batas normal adalah sebanyak 71 orang. Presentase IMT normal dengan hipertensi 0,72\%, sedangkan IMT normal dengan tekanan darah dalam batas normal 50,71\%

Tabel 3. Distribusi Indeks massa tubuh dan tekanan darah

\begin{tabular}{|l|l|l|l|}
\hline \multicolumn{1}{|r|}{ TD } & Hipertensi & Normal & Total \\
\hline Obesitas & $2(1,42 \%)$ & $8(5,71 \%)$ & 10 \\
\hline Overweight & $14(10 \%)$ & $44(31,42 \%)$ & 58 \\
\hline Normal & $1(0,72 \%)$ & $71(50,71 \%)$ & 72 \\
\hline Total & $\begin{array}{l}17 \\
(12,4 \%)\end{array}$ & $\begin{array}{l}113 \\
(87,86 \%)\end{array}$ & 140 \\
\hline
\end{tabular}


Tabel 4. Persentase indeks massa tubuh terkait hipertensi

\begin{tabular}{|c|c|c|c|}
\hline $\begin{array}{l}\text { IMT } \\
\text { Dekanan } \\
\text { Darah }\end{array}$ & Obesitas & Overweight & Normal \\
\hline $\begin{array}{l}\text { Hipertensi } \\
\text { (17) }\end{array}$ & $\begin{array}{l}2 \\
(11,76 \%)\end{array}$ & $\begin{array}{l}14 \\
(82,35 \%)\end{array}$ & $\begin{array}{l}1 \\
(0,58 \%)\end{array}$ \\
\hline
\end{tabular}

Dari tabel diatas dapat dijelaskan, bahwa persentase penderita hipertensi dosen umur 40-59 tahun di lingkungan Undiksha adalah 12,4 \% (17 orang) dari total sampel 140 orang. Persentase penderita hipertensi yang mengalami obesitas sebanyak 11,76\% (2 orang). Persentase penderita hipertensi yang mengalami kegemukan sebanyak 82,53 \% (14 orang). Sedangkan Persentase penderita hipertensi yang indek masa tubuhnya normal sebanyak 0,58\% (1 orang).

Untuk melihat hubungan antara variable indeks massa tubuh dan tekanan darah, dilakukan analisis dengan SPSS 16.0.

Untuk menganalisa data deskriptif, dilakukan dengan analisis univariat untuk mengetahui deskripsi masing-masing variable. Hasilnya sebagai berikut :

Tabel 5. Analsis deskriptif IMT, Sistolik, Diastolik dosen Undiksha umur 40-59 tahun.

\begin{tabular}{|l|l|l|l|l|l|}
\hline Variabel & $\mathrm{N}$ & Range & Min & Max & Std \\
\hline IMT & 140 & 14.21 & 20.31 & 34.53 & 2,73 \\
\hline Diastolik & 140 & 60 & 60 & 120 & 10.70 \\
\hline Sistolik & 140 & 90 & 90 & 180 & 12.99 \\
\hline
\end{tabular}

Dari tabel diatas dapat jelaskan,, rata-rata Indeks Masa Tubuh (IMT) sebesar 25,52 dengan simpangan baku sebesar 2,73. Rata-rata tekanan darah diastolic sebesar78 57 dengan simpangan baku sebesar 10,70. Rata-rata tekanan darah sistolik sebesar 119,64 dengan simpangan baku 12,99. 
Untuk mengetahui hubungan antara indeks massa tubuh dan hipertensi, maka dilakukan analisis bivariat (korelasi pearson product momen). Hasil analisisnya sebagai berikut :

Tabel 6. Analisis Bivariat hubungan IMT dengan IMT danI darah.

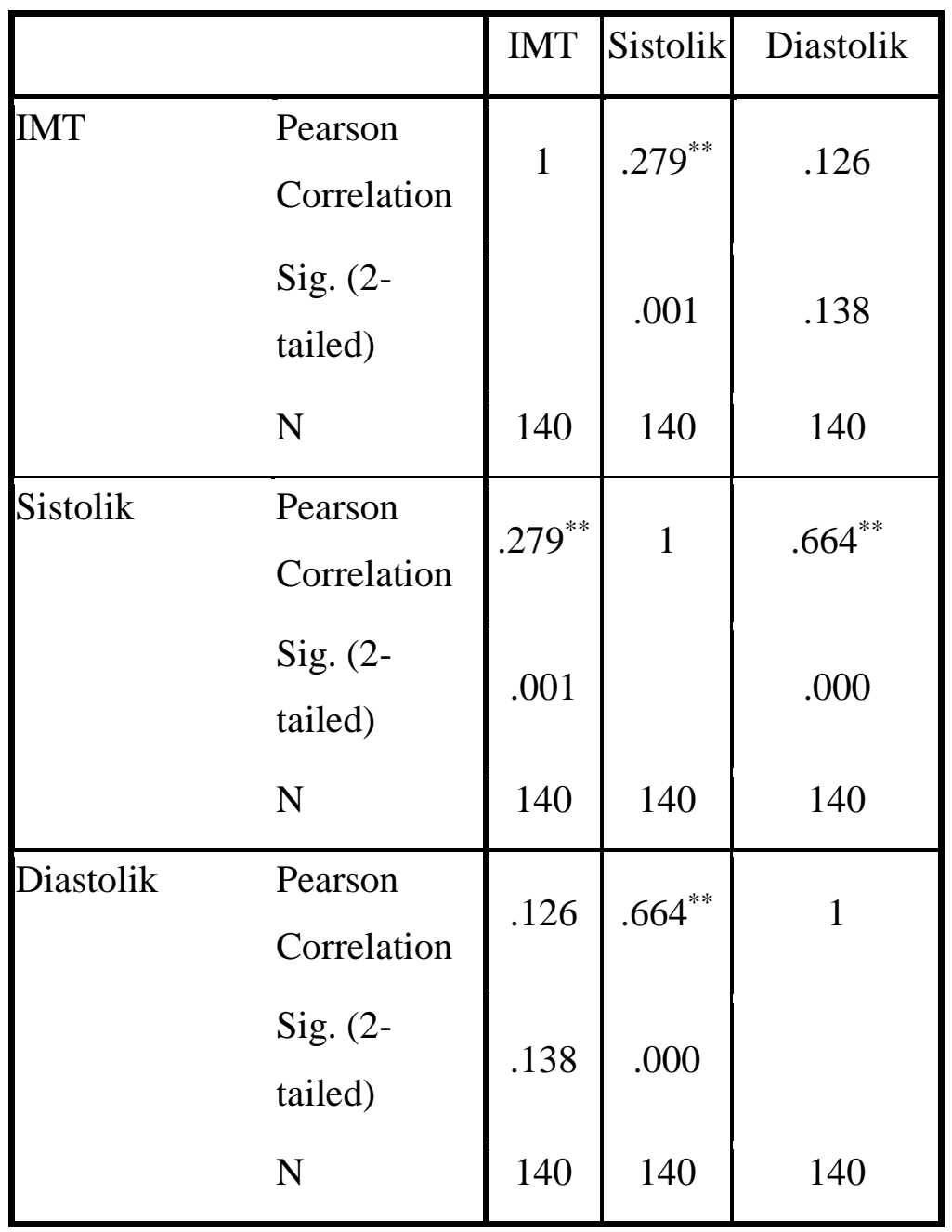

Dari tabel diatas dapat dijelaskan terdapat hububan yang signifikansi antara indek masa tubuh dengan tekanan darah sistolik $\mathrm{p}<0,001$, tapi tidak ada hubungan antara indeks massa tubuh dengan tekanan darah diastolic $\mathrm{p}=0138$. 


\section{PEMBAHASAN}

\section{Prevalensi Hipertensi Berdasarkan Indeks Massa Tubuh pada Dosen di Lingkungan Undiksha 40-59 Tahun.}

Kejadian hipertensi dipengaruhi oleh banyak faktor, dan faktor-faktor resiko tersebut dibedakan menjadi dua yaitu faktor yang bisa dimodifikasi dan faktor yang tidak bisa dimodifikasi. Obesitas atau kelebihan berat badan merupakan salah satu faktor yang dapat dimodifikasi yang berhubungan dengan peningkatan kejadian hipertensi. Pada penelitian ini didapatkan jumlah penderita hipertensi sebanyak 17 orang, dengan prevalensi hipertensi ditemukan sebanyak 12,14 \%. Dari 12,14 \% dosen yang mengalami hipertensi ditemukan sebanyak 11,76\% menderita obesitas, dan 82,35\% menderita overweight (kegemukan), hanya ), 0,58 \% penderita hipertensi memiliki berat badan dalam batas normal. Penemuan ini menguatkan penelitian sebelumnya, bahwa obesitas dan kegemukan meningkatkan resiko untuk menderita hipertensi.

\section{Hubungan antara Hipertensi dengan Indeks Massa Tubuh}

Pada penelitian ini didapatkan hubungan yang sangat kuat antara hipertensi dan indeks massa tubuh. Tekanan darah, pada penelitian ini kita bagi menjadi tekanan darah sistolik dan diastolic, didapatkan hubungan antara indeks massa tubuh dan tekanan darah sistolik yaitu $\mathrm{p}<0,001$, akan tetapi tidak didapatkan hubungan yang signifikan antara indeks massa tubuh dan tekanan darah diastolic $\mathrm{p}=0,138$. Setelah data tekanan darah diubah data menjadi katagorikal terdapat hubungan yang signifikan antara indeks massa tubuh dengan $\mathrm{p}<0,05(0,02)$. Penelitian ini menguatkan penemuan sebelumnya bahwa terdapat hubungan yang kuat antara hpertensi dan indeks massa tubuh. Hal ini dapat dijelaskan oleh teori Hall (1994) perubahan fisiologis dapat menjelaskan hubungan antara kelebihan berat badan dengan tekanan darah, yaitu terjadinya resistensi insulin dan hiperinsulinemia, aktivasi saraf simpatis dan sistem renin-angiotensin, dan perubahan fisik pada ginjal. Peningkatan konsumsi energi juga meningkatkan insulin plasma, dimana natriuretik 
potensial menyebabkan terjadinya reabsorpsi natrium dan peningkatan tekanan darah secara terus menerus (Cortas, 2008).

\section{KESIMPULAN}

Simpulan dari penelitian di atas, yaitu sebagai berikut.

1. Terjadi peningkatan resiko hipertensi lebih besar pada penderita obesitas dan kegemukan pada dosen undiksha umum 40-59 tahun.

2. Terdapat hubungan antara hipertensi dengan indek masa tubuh pada dosen undiksha umum 40-59 tahun.

\section{DAFTAR PUSTAKA}

Badan Penelitian dan Pengembangan Kesehatan, 2008. Laporan Riskesdas Nasional tahun 2007, Jakarta: Departemen Kesehatan RI.

Cortas, K. (2008, May 11- last update), “High Blood Pressure”, (emedicine.com), Available at : http://www.emedicinehealth.com/high_blood_pressure/page2_ em.htm (Accessed : 2011, February 14)

Dinas Kesehatan Kabupaten Buleleng, 2010, Pola Sepuluh Besar Penyakit di Kabupaten Buleleng, Dinas Kesehatan Kabupaten Buleleng, Singaraja

Dreisbach, A.W. (2010, February 9- last update), “Hypertension”, (emedicine.medscape.com), Available at : http://emedicine.medscape. com/article/241381-overview (Accessed : 2011, February 14).

Eaton, C.B. 2008, Hypertension, In : Mengel, M.B., Schwiebert, L.P. (eds) Family Medicine Ambulatory Care and Prevention, $5^{\text {th }}$ ed, Mc Graw Hill, USA

“Essential Hypertension”, (2008, April 17-last update), (www.X-plain.com), Available: http://www.X-plain.com/hypertension/overview.html (Accessed : 2011, February 14)

Fauci, A.S., Longo, D.L, 2008, Hypertensive Vascular Disease, in : Fauci, A.S., Longo, D.L., Kasper, D.L., Braunwald, Eugene., Hauser, S.L., Jameson, 
J.L., Loscalzo, Joseph. (eds) Harrisons's Principles of Internal Medicine, $17^{\text {th }}$ ed, Mc Graw Hill, USA

“High Blood Pressure Complication”, (2007, April 11-last update), (righthealth.com), Available at http://www.righthealth.com/topic /High_Blood_Pressure_Complications/overview/adam (Accessed : 2011, February 14)

Kearney, P.M., Whelton, Megan., Reynolds, Kristi., Muntner, Paul., Whelton, P.K., He, Jiang. 2005, “Global Burden of Hypertension : Analysis of Worldwide Data”, The Lancet, vol. 365, no. 9455.

Kuswardhani, T.RA., 2006, “Penatalaksanaan Hipertensi pada Lanjut Usia”, Jurnal Penyakit Dalam, vol. 7, no. 2. hal. 135-140

Kumar, K., Abbas, A.K., Fausto, N. 2005, Hypertensive Vascular Disease, In : Robn and Cotran Patologic Basic of Disease, $7^{\text {th }}$ ed, Elseviers Saunders, Philadelpia

Kulkarni, S., O’Farrel, I., Erasi,M., Kochar, MS. 1998, “Stress and Hypertension”, WMJ, vol.11, pp.34-38

Shapo, L., Pomerleau , J., McKee , M. 2003, “Epidemiology of Hypertension and Associated Cardiovascular Risk Factors in a Country in Transition “,Journal Epidemiology Community Health, vol. 57, pp. 734-739

Sugiyono, 2007, Stastitika Untuk Penelitian, Alfabeta, Bandung

WHO Western Pasific Region, 2000, The Asia-Pasific perspective: Redefining obesity and its treatment.

WHO, 1998, Obesity : Preventing and Managing the Global Epidemic, Geneva.

Yogiantoro M, 2006, Hipertensi Esensial dalam Buku Ajar Penyakit Dalam Jilid I Edisi ke IV, FK UI, Jakarta 